\title{
KELEKATAN ANAK DENGAN IBU DAN AYAH SERTA PERILAKU PORNOGRAFI PADA ANAK USIA SMP
}

\author{
Rika Hardani ${ }^{* *}$, Dwi Hastuti ${ }^{2}$, Lilik Noor Yuliati \\ ${ }^{1}$ Program Studi IImu Keluarga dan Perkembangan Anak, Sekolah Pascasarjana, Institut Pertanian Bogor, \\ ${ }^{2}$ Departemen IImu Keluarga dan Konsumen, Fakultas Ekologi Manusia, Institut Pertanian Bogor, Bogor \\ 16680, Indonesia \\ *)Email: rikahardani@yahoo.com
}

\begin{abstract}
Abstrak
Kelekatan anak dengan ibu dan ayah yang terbentuk sejak kecil, akan memengaruhi perkembangan kepribadian anak kelak. Kepribadian yang baik akan membuat anak mampu memilih perilaku yang baik dan tidak terjerumus kedalam perilaku negatif seperti perilaku pornografi. Tujuan penelitian adalah menganalisis pengaruh kelekatan ibu-anak dan kelekatan ayah-anak terhadap perilaku pornografi anak usia Sekolah Menengah Pertama (SMP). Pemilihan lokasi dilakukan secara purposive di Kota Tangerang Selatan. Sebanyak 600 anak usia SMP yang terdiri atas 278 laki-laki dan 322 perempuan terpilih menjadi contoh dengan menggunakan teknik cluster random sampling dengan kelas sebagai cluster dari sekolah terpilih di lokasi penelitian. Responden dalam penelitian diminta untuk mengisi kuesioner pengembangan dari Inventory of Parent and Peer Attachment (IPPA) dan kuesioner perilaku pornografi yang disusun peneliti. Data dianalisis dengan analisis deskriptif, uji korelasi dan uji regresi. Hasil penelitian menunjukkan bahwa pada anak laki-laki dan perempuan, skor kelekatan ibu lebih tinggi dari skor kelekatan ayah. Perilaku pornografi pada anak laki-laki ditemukan lebih tinggi daripada anak perempuan. Kelekatan ibu dan kelekatan ayah memperlihatkan hubungan yang negatif signifikan dengan perilaku pornografi. Hasil analisis regresi menunjukkan bahwa pendapatan keluarga berpengaruh positif signifikan terhadap perilaku pornografi. Sebaliknya, kelekatan ibu dan kelekatan ayah berpengaruh signifikan negatif terhadap perilaku pornografi.
\end{abstract}

Kata kunci: kelekatan ayah, kelekatan ibu, perilaku pornografi

\section{Mother's Attachment, Father's Attachment and Pornography Behaviour of The Middle Secondary School Age Children}

\begin{abstract}
The mother's attachment and father's attachment with children were formed since childhood, will influence the future development of the child's personality. A good personality will make children able to choose good behavior and not to fall into negative behaviors such as behavioral pornography. The research aimed is to analyze the influence of mother-child's attachment and father-child's attachment on the behavior of school-age child pornography (SMP). The choice of location was purposively in South Tangerang City. A total of 600 children aged junior consisting of 278 men and 322 women were selected using cluster random sampling technique with the class as a cluster of selected schools in the study sites. Respondents were asked to fill out questionnaires of the Inventory of Parent and Peer Attachment (IPPA) and the questionnaire Pornography Behavior. Data were analyzed with descriptive analysis, correlation, and regression. The results showed that the boys and girls of mother's attachment score higher than father's attachment scores. Behavior pornography on boys is higher than girls. The mother's attachment and father's attachment showed a significant negative correlation with the behavior of pornography. Regression analysis showed that family income significant positive effect on the behavior of pornography. Instead, the mother's attachment and father's attachment significant negative effect on the behavior of pornography.
\end{abstract}

Keywords: father's attachment, mother's attachment, pornography behavior

\section{PENDAHULUAN}

Pengalaman di periode anak berperan penting dalam pembentukan karakter di usia dewasa. Hubungan yang sangat istimewa antara seorang anak dengan ibu atau pengasuh utamanya terbentuk pada masa-masa awal kehidupan anak. Menurut Ainsworth (1979) hubungan kelekatan berkembang melalui pengalaman bayi dengan pengasuh di tahuntahun awal kehidupannya akan banyak memengaruhi pembentukan kepribadiannya. 
Armsden dan Greenberg (1987) melakukan penelitian pada remaja yang memperlihatkan bahwa kelekatan anak dengan orangtua berpengaruh terhadap kesejahteraan anak secara psikologi dalam hal kepercayaan anak pada orangtua, komunikasi serta perasaan terasing anak pada orangtua. Penelitian yang dilakukan Smallbone et al. (2000) menunjukkan bahwa kelekatan yang tidak aman pada anak dengan ibu dan ayah sewaktu kecil, berpengaruh pada perilaku antisosial, agresi, perilaku pornografi dan kekerasan seksual. Pada masa remaja awal, anak akan mulai menghadapi berbagai macam masalah dalam pergaulan, ada hal yang baik dan ada pula hal-hal yang negatif. Kedekatan anak dengan orang tua yang terbentuk sejak kecil diharapkan mampu membentengi anak dari perilaku negatif. Hubungan keluarga yang positif akan mengurangi kemungkinan anak terlibat dalam perilaku pornografi yang dilakukan secara online (Rivera et al., 2016).

Perilaku negatif yang mulai banyak dilakukan anak-anak dan remaja seiring dengan perkembangan teknologi saat ini adalah perilaku pornografi. Mariani dan Bachtiar (2010) mengungkapkan bahwa sekitar 91,0 persen siswa telah terpapar pada materi pornografi, dan materi pornografi paling banyak diakses melalui handphone yang merupakan alat komunikasi elektronik yang baru berkembang. Selanjutnya, Fadhli et al. (2014) menyatakan peningkatan problem sosial, diantaranya pornografi, dikarenakan kemajuan dalam hal teknologi. Penelitian tersebut lebih memfokuskan pada kemajuan alat komunikasi sebagai penyebab dari munculnya perilaku pornografi, padahal dalam kehidupan anak peran orangtua sangatlah berarti. Penelitian yang khusus meneliti pengaruh kelekatan ibu dan ayah terhadap perilaku pornografi anak usia SMP, masih relatif jarang dilakukan.

Kraus dan Rosenbergh (2014) menyatakan bahwa munculnya perilaku pornografi merupakan korelasi dari skor keinginan melihat pornografi dengan keasyikan pornografi, sejarah seksual, penggunaan internet kompulsif, dan mencari sensasi. Perilaku pornografi ini harus diwaspadai sejak awal, karena perilaku pornografi yang awalnya ringan dapat berkembang menjadi perilaku yang lebih parah. Apabila perilaku ini tidak dihentikan atau ditangani segera, maka akan bisa memunculkan perilaku salah yang lebih parah seperti kekerasan seksual, orientasi seks menyimpang, kehidupan romantis saat dewasa yang tidak menyenangkan bahkan bisa berakibat fatal seperti menjadi pembunuh yang didorong gairah seks yang tidak terpuaskan dan menyimpang (D'orlando, 2011). Hasil penelitian Luder et al. (2011) menemukan bahwa masalah-masalah yang dapat muncul dikarenakan intensitas yang tinggi pada menonton pornografi di antaranya melakukan seks bebas, kekerasan seksual, penurunan prestasi akademik, kecanduan pornografi, dan kelainan orientasi seks. Berdasarkan survei yang dilakukan Komisi Nasional Perlindungan Anak (2011) di 12 kota besar di Indonesia mengenai perilaku remaja, didapatkan sebanyak 83,0 persen remaja mengaku pernah menonton video porno, 93,7 persen pernah melakukan hubungan seksual, dan 21,0 persen remaja di Indonesia pernah melakukan aborsi.

Hasil temuan Sabina et al. (2008) menyatakan bahwa remaja yang berusia 13 dan 14 tahun lebih banyak mengonsumsi pornografi dibandingkan tahapan usia lainnya. Remaja usia 13 dan 14 tahun merupakan tahap usia perkembangan anak Sekolah Menengah Pertama (SMP) dan masa pencarian identitas. Rasa ingin tahu yang besar dapat mendorong mereka untuk melakukan perilaku pornografi, seperti melihat tontonan materi porno yang bisa memunculkan keinginan berhubungan intim (Seto et al., 2015). Materi tontonan pornografi ini mudah diperoleh anak dari internet secara online maupun buku-buku komik offline. Saat ini pengakses internet di Indonesia sebanyak 88,1 juta orang dan 50,0 persen adalah remaja (APJII, 2014). Jumlah pengakses internet sebanyak 74,0 persen tinggal di wilayah perkotaan dan sekitarnya. Selanjutnya, Romito dan Beltramini (2015) menemukan bahwa dibadingkan dengan remaja perempuan, remaja laki-laki lebih menyukai melihat pornografi karena pornografi merupakan sesuatu yang menarik.

Anak yang tinggal di wilayah perkotaan diduga jarang bertemu dengan orang tuanya. Kondisi jalan yang semakin padat membuat waktu tempuh menuju dan kembali dari tempat bekerja juga semakin lama. Kehilangan peran orang tua pada usia remaja akan sangat memengaruhi proses pencarian dan pembentukan identitas pada remaja (Santrock, 2011). Temuan Rivera et al. (2016) menunjukkan bahwa hubungan antar-anggota keluarga yang positif dapat menurunkan konsumsi pornografi remaja. Orang tua dan teman memainkan peran yang penting dan unik pada perilaku antisosial pada remaja (Mobarake et al., 2014). Lebih lanjut, Seto et al. (2015) menyatakan bahwa peran orang tua 
dan guru sangat penting untuk mengatasi pornografi.

Dilihat dari proses perkembangan anak, masamasa awal kehidupan anak dan interaksi anak dengan ayah dan ibunya di masa kecil menjadi fondasi awal bagi pembentukan kepribadian anak (Bowlby, 1988). Hubungan yang terbentuk di masa awal kehidupannya ini akan menjadi dasar bagi anak dalam menghadapi masalah di masa-masa yang akan datang. Berdasarkan hal tersebut, maka sangat dibutuhkan penelitian mengenai kelekatan anak dengan ibu dan ayah terhadap perilaku pornografi.Kebaruan dari penelitian ini adalah penggunaan variabel kelekatan ibu dan ayah dengan anak terhadap perilaku pornografi, sedangkan penelitian-penelitian sebelumnya lebih banyak menghubungkan kelekatan ibu dan ayah dengan kenakalan anak atau remaja (delinquency) secara umum, tidak khusus mengaitkannya dengan pornografi. Kenakalan anak dan remaja merupakan kumpulan dari berbagai perilaku yang tidak dapat diterima secara sosial di antaranya adalah perilaku pornografi dan perilaku seks bebas (Santrock, 2011). Penelitian Wampler dan Downs (2010) menemukan bahwa kondisi kelekatan yang tidak baik antara anak dengan orang tua, akan menyebabkan kenakalan dan perilaku bermasalah. Adapun tujuan penelitian ini adalah menganalisis pengaruh karakteristik anak dan keluarga, kelekatan ibu, kelekatan ayah terhadap perilaku pornografi pada anak usia SMP.

\section{METODE}

Desain penelitian ini menggunakan cross sectional study yaitu suatu penelitian yang dilakukan pada tempat dan satu waktu tertentu. Penelitian dilakukan di Kota Tangerang Selatan yang dipilih secara purposive dengan pertimbangan Kota Tangerang Selatan merupakan wilayah urban, penyangga ibukota, dan penggunaan internet relatif tinggi (APJII, 2014). Penelitian dilakukan pada bulan Juni hingga Oktober 2016.

Penelitian dilakukan di empat Sekolah Menengah Pertama (SMP) di Kota Tangerang Selatan yang dipilih secara purposive berdasarkan rekomendasi dari Dinas Pendidikan Nasional Kota Tangerang Selatan dengan kriteria SMP dengan kondisi sekolah yang berbeda dan siswanya berasal dari latar belakang ekonomi yang beragam, agar dapat menggambarkan beragam kondisi. Pemilihan contoh menggunakan teknik cluster random sampling dengan kelas 8 dan kelas 9 sebagai clustemya sehingga terpilih sebanyak 17 kelas dari 46 kelas. Selanjutnya diperoleh contoh sebanyak 278 anak laki-laki dan 322 anak perempuan.

Pengambilan data dilakukan dengan cara memberikan kuesioner yang diisi sendiri oleh contoh. Kuesioner yang digunakan untuk mengukur kelekatan ibu dan ayah yaitu Inventory of Parent and Peer Attachment (IPPA) (Armsden \& Greenberg, 1987) yang sudah dimodifikasi kuesioner kelekatan ibuanak dengan nilai cronbach alpha sebesar 0,800 . Validitas dari instrumen pengukuran kelekatan dengan ibu berkisar antara 0,100 sampai dengan 0,630. Sementara itu, nilai cronbach alpha kelekatan ayah dengan anak adalah 0,810. Validitas dari instrumen pengukuran kelekatan dengan ayah berkisar antara 0,20 sampai dengan 0,56.

Kuesioner kelekatan remaja dengan ibu dan ayah ini terdiri dari tiga dimensi (kepercayaan/trust $10 \quad$ butir, komunikasi/communication 9 butir, keterasingan/alienation 6 butir). Skala yang digunakan yaitu skala Likert 1-4 (1= sangat tidak setuju, 2= tidak setuju, $3=$ setuju, $4=$ sangat setuju). Kelekatan anak dengan ibu dan ayah dimensi kepercayaan diukur dengan pertanyaan misalnya sebagai berikut. "Pada saat saya ada masalah, ibu/ayah memahami apa yang saya rasakan." Contoh lain," Saya percaya pada ibu/ayah."; "Ibu/ayah menerima kondisi saya apa adanya." Dimensi komunikasi diukur dengan pertanyaan misalnya sebagai berikut. "Saya suka jika ibu/ayah memberikan pendapat tentang suatu hal yang saya sukai." Atau contoh lain," Saya bercerita pada ibu/ayah tentang problem dan kesulitan saya." Dimensi keterasingan diukur dengan pertanyaan misalnya sebagai berikut. "Saya merasa dipermalukan ibu/ayah, kalau menceritakan problem saya." Atau pertanyaan," Saya merasa tidak mendapat banyak perhatian dari ibu/ayah.'Contoh pertanyaan lainnya," Saya mudah marah bila ada di dekat ibu/ayah."

Perilaku pornografi diukur dengan menggunakan skala Likert 1-3 ( $1=$ tidak pernah, 2=jarang, $3=$ sering) dengan nilai cronbach alpha 0,700. Validitas dari instrumen pengukuran perilaku pornografi berkisar antara $0,170-0,520$. Perilaku pornografi diukur dengan pernyataan seperti: "Saya bermain games yang ada adegan memperlihatkan anggota tubuh intim" dan "Saya diajak teman untuk membaca komik porno". 
Pengategorian variabel kelekatan remaja-ibu, kelekatan remaja-ayah, dan perilaku pornografi menggunakan nilai indeks masing-masing variabel berdasarkan standar nilai normatif dengan cut off point rendah $(0,0-60,0)$, sedang $(60,1-80,0)$, dan tinggi $(80,1-100,0)$. Penetapan standar menggunakan ukuran normatif pada variabel kelekatan remaja-ibu dan remajaayah, serta perilaku pornografi diharapkan dapat menggambarkan kualitas variabel dengan lebih baik (Situmorang et al., 2016). Pengukuran pendapatan keluarga dengan berdasarkan pada nilai Upah Minimum Regional (UMR) untuk wilayah Tangerang Selatan berkisar Rp2.000.000,00 Rp2.700.000,00 (Disnakertrans, 2014).

Data yang diperoleh diolah terlebih dahulu melalui proses editing, coding, scoring, entry data, cleaning, dan analisis data menggunakan Microsoft Excel dan SPSS for windows versi 22. Analisis yang digunakan yaitu analisis deskriptif dan analisis inferensial. Analisis deskriptif yang digunakan adalah nilai rata-rata, standar deviasi, nilai minimum, nilai maksimum serta frekuensi. Analisis inferensial yang digunakan untuk menjawab tujuan penelitian adalah uji regresi. Uji regresi linear berganda dilakukan juga untuk menguji pengaruh karakteristik anak dan keluarga, kelekatan ibu, kelekatan ayah terhadap perilaku pornografi. Di samping itu, uji beda $t$ test juga digunakan untuk melihat apakah terdapat perbedaan kelekatan ibu, kelekatan ayah, dan perilaku pornografi pada anak lakilaki dan anak perempuan.

\section{HASIL}

\section{Karakteristik Anak}

Penelitian ini melibatkan sebanyak 600 contoh yang terdiri dari 278 anak laki-laki $(46,3 \%)$ dan 322 anak perempuan (53,7\%). Setiap anak memiliki tahap perkembangan yang berbeda dan usia adalah salah satu faktor yang dapat mengetahui tahap perkembangan dari seseorang. Hasil penelitian menemukan bahwa rentang usia anak berkisar antara 12 sampai 16 tahun dengan rata-rata 13,4 tahun. Sebanyak 40,4 persen contoh adalah anak pertama, artinya adik-adik yang dimiliki masih sekitar 2-4 orang dan kemungkinan ada yang balita, karena usia contoh paling banyak berusia 12-13 tahun. Adanya adik kemungkinan dapat membuat perhatian orangtua terbagi.

Contoh memperoleh fasilitas yang beragam yang diperoleh dari orang tua. Jumlah uang jajan anak bervariasi mulai kurang dari Rp25.000,00 sampai lebih dari Rp150.000,00 setiap minggunya. Sebanyak 60,1 persen anak laki-laki dan 58,2 persen anak perempuan memiliki perangkat elektronik sebanyak satu buah dan yang terbanyak jenisnya adalah handphone. Handphone dengan harga yang tidak terlalu mahal juga bisa digunakan untuk mengakses internet. Anak laki-laki yang menggunakan internet paket berlangganan sebanyak 51,5 persen dan anak perempuan sebanyak 60,2 persen. Biaya untuk membeli paket berlangganan ini pada anak laki-laki diperoleh dari uang jajan $(48,2 \%)$ dan pada anak perempuan diberi oleh orang tua selain dari uang jajan (43,7\%). Sebanyak 59,7 persen contoh anak laki-laki dan 76,5 persen anak perempuan mengakses internet dari rumah.

\section{Karakteristik Keluarga}

Hasil penelitian menemukan bahwa sebanyak 74,3 persen ayah berusia pada dewasa menengah (41-60 tahun) dengan rata-rata usia ayah 44,9 tahun. Penelitian menemukan bahwa sebanyak 54,9 persen ibu juga berada pada rentang usia dewasa madya atau menengah (18-40) tahun dengan rata-rata usia ibu 41,9 tahun. Usia ayah dan ibu berkisar dari 24 sampai 65 tahun. Rata-rata usia ayah dan ibu yang berada pada rentang dewasa menengah menunjukkan kondisi yang sudah stabil, baik dari segi emosi maupun sosialekonomi.

Hasil penelitian menemukan bahwa sebanyak 37,2 persen pendidikan ayah adalah lulus SMA. Ayah yang mendapat pendidikan S1 sebanyak 18,2 persen. Sebanyak 34,0 persen ibu berpendidikan lulusan SMA. Pendidikan ayah dan ibu memperlihatkan bahwa dari sisi pengetahuan sudah memperoleh cukup bekal untuk mencari pendapatan dan membina keluarga.

Hasil penelitian menunjukkan bahwa sebanyak 67,5 persen contoh memiliki jumlah keluarga 5-7 orang. Jumlah keluarga yang relatif banyak ini, memungkinkan anak untuk melatih kemampuan sosial emosionalnya. Keluarga yang lebih banyak anggotanya juga memungkinkan menurunnya rasa kesepian selama di rumah, namun dapat juga menyebabkan konflik antarsaudara sekandung, serta terbaginya waktu dan perhatian orang tua kepada anggota keluarga yang lain.

Sebanyak 45,2 persen ayah dari contoh bekerja sebagai karyawan swasta. Sebanyak 
62,7 persen ibu dari contoh adalah ibu rumahtangga. Ibu rumahtangga seharusnya memiliki banyak waktu untuk lebih memerhatikan anak bila tidak ada aktivitas lain. Pendapatan memiliki pengaruh dalam keluarga, yaitu ikut menentukan keputusan bagi keluarga dalam memberikan kebutuhan anak baik secara fisik maupun non fisik (Zhang, 2012). Penelitian ini menemukan jumlah pendapatan orang tua contoh sangat beragam. Sebanyak 29,7 persen keluarga memiliki pendapatan sebesar Rp1.000.001,00 sampai Rp3.000.000,00. Sebanyak 22,5 persen keluarga memiliki pendapatan Rp3.000.001,00 sampai Rp5.000.000,00. Sementara itu, terdapat 16,5 persen keluarga yang memiliki pendapatan di atas Rp11.000.000,00.

\section{Kelekatan Ibu dan Kelekatan Ayah}

Skor kelekatan anak dengan ibu berkisar antara 62,0 sampai dengan 100,0 . Rata-rata skor kelekatan ibu sebesar 81,5. Hasil penelitian ini menunjukkan bahwa kelekatan ibu pada anak usia SMP ini tergolong tinggi, bila dilihat dari nilai rata-ratanya. Sementara itu, kelekatan ayah bila dilihat dari nilai rataratanya berada pada kategori sedang dengan indeks rata-rata sebesar 78,9 seperti yang ditunjukkan pada Tabel 1.

Kelekatan ibu dengan anak memperlihatkan bahwa nilai rata-rata yang paling tinggi terlihat pada dimensi kepercayaan. Tingginya kepercayaan anak pada ibu tergambar dari jawaban pertanyaan dalam kuesioner yang diisi oleh anak. Sebanyak 83,7 persen anak percaya pada ibu. Pada saat ada masalah, ibu memahami yang anak rasakan. Hasil penelitian menemukan tidak ada anak yang mengharapkan memiliki ibu selain ibunya sekarang. Anak juga menilai bahwa ibu sudah melakukan tugasnya dengan baik $(98,4 \%)$. Tingginya skor kepercayaan pada kelekatan ibu dapat dipahami karena sejak kecil anak dirawat dan lebih banyak diasuh oleh ibu daripada ayah.

Tabel 1 Sebaran indeks rata-rata dan standar deviasi kelekatan ibu dan kelekatan ayah

\begin{tabular}{lcc}
\hline \multicolumn{1}{c}{ Dimensi } & $\begin{array}{c}\text { Kelekatan Ibu } \\
\text { Rata-rata } \pm \text { SD }\end{array}$ & $\begin{array}{c}\text { Kelekatan ayah } \\
\text { Rata-rata } \pm \text { SD }\end{array}$ \\
\hline Kepercayaan & $37,1 \pm 2,4$ & $34,9 \pm 4,1$ \\
Komunikasi & $26,1 \pm 3,9$ & $29,4 \pm 4,5$ \\
Keterasingan & $18,2 \pm 3,2$ & $14,6 \pm 4,9$ \\
\hline Minimum- & $62-100$ & $53-100$ \\
maksimum & & \\
$\begin{array}{l}\text { Skor } \\
\text { keseluruhan }\end{array}$ & $81,5 \pm 7,9$ & $78,9 \pm 9,8$ \\
\hline
\end{tabular}

Dibandingkan kelekatan ibu dengan anak, kelekatan ayah dengan anak pada dimensi kepercayaan skornya lebih rendah $(76,9 \%)$. Anak merasa bahwa ayah dapat menerima kondisi mereka apa adanya (64,7\%). Komunikasi pada kelekatan ayah $(29,4 \%)$ lebih tinggi nilai rata-ratanya daripada kelekatan ibu $(26,1 \%)$. Pertanyaan yang memperoleh nilai lebih tinggi pada kelekatan ayah daripada kelekatan ibu, misalnya, sebagian besar anak $(88,4 \%)$ sangat setuju bahwa ayah mengetahui kapan anak sedang marah. Lebih dari setengah anak $(60,2 \%)$ sangat setuju bahwa ayah membantu anak untuk memahami diri mereka secara lebih baik. Hanya 39,3 persen anak yang sangat setuju bahwa ibu akan membantu anak memahami diri mereka. Pernyataan bahwa anak menyukai kalau ayah memberikan pendapat tentang sesuatu yang disukai anak, dijawab sangat setuju oleh 59,3 persen anak, sedangkan untuk pernyataan yang sama pada kelekatan ibu, sebanyak 73,0 persen anak sangat setuju.

Keterasingan pada kelekatan ibu dan ayah dapat digambarkan, misalnya, dengan sikap malu anak untuk menceritakan masalahnya pada orang tua, ada perasaan marah bila berdekatan dengan orang tua, atau ketidaktahuan orang tua akan kondisi anak. Sebanyak 49,8 persen anak menjawab sangat setuju kalau mereka merasa tidak mendapat perhatian banyak dari ibunya, dan 30,1 persen lainnya menjawab setuju dengan pernyataan ini. Anak juga merasa mudah marah bila berada didekat ibu (52,1\%). Perasaan marah ini disebabkan oleh banyak hal, salah satunya anak mengira bahwa ibu tidak mengetahui perasaan marah yang mereka alami. Sebanyak 32,6 persen anak merasa malu untuk menceritakan masalahnya pada ibu, sedangkan pada ayah hanya 15,5 persen anak yang merasa malu untuk menceritakan masalahnya. Seorang ibu seharusnya memiliki kepekaan dan empati yang tinggi akan perasaan anak. Respons orang tua yang segera bila melihat kondisi anak yang sedang marah atau kesal akan meningkatkan nilai kelekatan anak dengan orang tua (Ainsworth, 1979).

Penelitian ini juga menunjukkan bahwa persentase anak terbanyak dalam penelitian ini memiliki skor pada kategori sedang untuk kelekatan ibu $(60,8 \%)$, demikian pula pada kelekatan ayah (54,2\%) (Tabel 2). Namun demikian, pada kelekatan ayah, persentase anak yang termasuk dalam kategori tinggi lebih besar $(28,0 \%)$ dibandingkan dengan kategori tinggi pada kelekatan ibu (16\%). 
Tabel 2 Sebaran contoh berdasarkan kategori kelekatan ibu dan kelekatan ayah

\begin{tabular}{lrc}
\hline \multicolumn{1}{c}{ Kategori variabel } & $\mathrm{n}$ & $\%$ \\
\hline Kelekatan ibu & & \\
Rendah $(0,0-60,0)$ & 139 & 23,2 \\
Sedang $(60,1-80,0)$ & 365 & 60,8 \\
Tinggi $(80,1-100,0)$ & 96 & 16,0 \\
\hline Kelekatan ayah & & \\
Rendah $(0,0-60,0)$ & 107 & 17,2 \\
Sedang $(60,1-80,0)$ & 325 & 54,2 \\
Tinggi $(80,1-100,0)$ & 168 & 28,0 \\
\hline
\end{tabular}

\section{Perilaku Pornografi}

Undang-undang RI Nomor 44 tahun 2008 tentang pornografi menjelaskan yang dimaksud pornografi adalah gambar, sketsa, ilustrasi, foto, tulisan, suara, bunyi, gambar bergerak, animasi, kartun, percakapan, gerak tubuh, atau bentuk pesan lainnya melalui berbagai bentuk media komunikasi dan/atau pertunjukan di muka umum, yang memuat kecabulan atau eksploitasi seksual yang melanggar norma kesusilaan dalam masyarakat (Kementerian Agama RI, 2008)

Hasil penelitian menunjukkan bahwa nilai ratarata perilaku pornografi secara statistik berbeda $(p=0,03, p<0,05)$ pada anak laki-laki $(14,6)$ lebih tinggi daripada anak perempuan $(13,2)$. Pertanyaan yang menunjukkan perbedaan signifikan pada anak laki-laki dan perempuan yaitu (1) melihat situs porno setiap hari, (2) bermain games porno, (3) merayu pacar lewat telpon atau skype, (4) dipaksa teman melihat film porno, (5) saat bermain dengan teman lawan jenis, terbayang adegan porno.

Anak laki-laki yang pernah (jarang dan sering) melihat situs porno setiap hari sebanyak 23,4 persen, sedangkan anak perempuan sebanyak 5,3 persen. Fasilitas telepon genggam atau peralatan elektronik yang dimiliki anak, membuat anak mudah untuk dapat mengakses internet. Bermain games adalah salah satu bentuk aktivitas yang disukai anak saat mengakses internet. Konten dari games tersebut juga bermacam-macam. Bermain games porno pernah dilakukan oleh 18,0 persen anak laki-laki dan 3,4 persen anak perempuan. Bentuk perilaku pornografi lain adalah pornografi melalui ucapan yang dapat memunculkan nafsu birahi. Anak laki-laki yang pernah merayu pacar lewat telpon atau skype sebanyak 26,1 persen dan anak perempuan sebanyak 13,6 persen. Faktor pendorong anak melakukan perilaku pornografi juga beragam. Ada yang melakukannya dengan sukarela, ada yang awalnya diajak teman, ada juga karena dipaksa oleh teman. Anak laki-laki yang pernah dipaksa teman untuk melihat film porno sebanyak 21,3 persen, sedangkan anak perempuan sebanyak 16,1 persen. Pikiranpikiran negatif membayangkan hal-hal porno juga termasuk dalam perilaku pornografi. Pikiran-pikiran ini bila tidak dihentikan, akan berbahaya karena dapat memunculkan dorongan untuk melakukan secara nyata. Sebanyak 15,4 persen anak laki-laki mengaku pernah terbayang adegan porno saat bermain dengan teman.

Analisis korelasi menunjukkan adanya hubungan negatif signifikan kelekatan ibu dengan perilaku pornografi anak laki-laki $(r=-$ $0,521, \quad r<0,01)$ dan anak perempuan $(r=-$ $0,541, p<0,01)$. Hasil menunjukkan pada semua dimensi kelekatan ibu (kepercayaan, komunikasi, keterasingan), terdapat hubungan negatif signifikan, dimana $p<0,01$. Hal ini berarti semakin tinggi kelekatan ibu maka perilaku pornografi akan cenderung semakin menurun, baik pada anak laki-laki maupun anak perempuan. Pada variabel kelekatan ayah, menunjukkan adanya hubungan negatif signifikan dengan perilaku pornografi anak lakilaki $(r=-0,488, p<0,01)$ dan anak perempuan $(r=-0,497, \quad p<0,01)$. Ketiga dimensi dari kelekatan ayah, juga memperlihatkan hubungan negatif signifikan dengan perilaku pornografi.

\section{Pengaruh Karakteristik Anak, Karakteristik Keluarga, Kelekatan Ibu, Kelekatan Ayah terhadap Perilaku Pornografi}

Hasil analisis regresi linier berganda terhadap perilaku pornografi anak memiliki nilai koefisien determinasi $\left(R^{2}\right)$ sebesar 0,34 artinya sebesar 34,0 persen perilaku pornografi anak dipengaruhi oleh karakteristik anak, karakteristik keluarga, kelekatan ibu, dan kelekatan ayah. Sisanya dijelaskan oleh variabel lain di luar variabel yang digunakan dalam penelitian ini. Variabel yang memiliki pengaruh signifikan terhadap perilaku pornografi anak adalah pendapatan keluarga, kelekatan ibu dan kelekatan ayah. Hasil penelitian juga memperlihatkan bahwa kelekatan ibu dan kelekatan ayah memperlihatkan hubungan yang negatif signifikan dengan perilaku pornografi. Hasil penelitian menunjukkan bahwa pendapatan keluarga $\left(\beta=0,127, \quad p=0,000^{* *}\right)$, kelekatan remaja-ibu $\quad\left(\beta=-0,369, \quad p=0,000^{* *}\right)$ serta kelekatan remaja-ayah $\left(\beta=-0,243, p=0,000^{* *}\right)$ menjadi indikator penting yang memengaruhi perilaku pornografi anak (Tabel 3). 
Tabel 3 Pengaruh karakteristik anak, karakteristik keluarga, kelekatan ibu, dan kelekatan ayah terhadap perilaku pornografi

\begin{tabular}{|c|c|c|c|}
\hline Variabel & $\begin{array}{c}\text { B } \\
\text { (Tidak terstandarisasi) }\end{array}$ & $\begin{array}{c}\beta \\
\text { (Terstandarisasi) }\end{array}$ & Sig. \\
\hline Konstanta & 35,799 & & 0,000 \\
\hline Usia Anak & 0,462 & 0,043 & 0,197 \\
\hline Jenis Kelamin & 0,015 & 0,001 & 0,979 \\
\hline Usia Ayah & 0,083 & 0,057 & 0,176 \\
\hline Usia lbu & 0,024 & 0,017 & 0,683 \\
\hline Pendidikan Ayah & $-0,080$ & $-0,023$ & 0,668 \\
\hline Pendidikan Ibu & 0,027 & 0,007 & 0,889 \\
\hline Pendapatan Ayah & 0,407 & 0,127 & 0,004 \\
\hline Besar Keluarga & $-0,239$ & $-0,034$ & 0,314 \\
\hline Kelekatan Ibu & $-0,291$ & $-0,369$ & 0,000 \\
\hline Kelekatan Ayah & $-0,154$ & $-0,243$ & 0,000 \\
\hline $\mathrm{F}$ & \multicolumn{3}{|c|}{31,522} \\
\hline Sig. & \multicolumn{3}{|c|}{0,000} \\
\hline $\mathrm{R}^{2}$ & \multicolumn{3}{|c|}{0,349} \\
\hline Adj. $R^{2}$ & \multicolumn{3}{|c|}{0,338} \\
\hline
\end{tabular}

Hasil analisis menunjukkan bahwa setiap peningkatan satu skor pendapatan keluarga, dapat meningkatkan 0,127 poin perilaku pornografi anak. Kenaikan pendapatan keluarga tentunya akan meningkatkan pula kesejahteraan keluarga tersebut. Pemanfaatan pengeluaran keluarga yang tepat, akan membawa kebaikan bagi keluarga dan setiap anggota keluarga. Sebaliknya, pemakaian pendapatan yang tidak tepat, dapat mengakibatkan hal-hal yang tidak diharapkan. Menurut penelitian Jonsson et al. (2015), lifestyle (gaya hidup) merupakan salah satu faktor yang berpengaruh pada perilaku pornografi. Temuan lain menunjukkan bahwa setiap peningkatan satu skor kelekatan remaja-ibu, dapat menurunkan perilaku pornografi sebesar 0,369 poin. Peningkatan satu skor kelekatan remaja-ayah dapat menurunkan perilaku pornografi sebesar 0,243 poin.

\section{PEMBAHASAN}

Kelekatan yang terjadi antara orang tua dengan anak yang berlangsung dua arah dan dalam waktu yang cukup lama serta melibatkan emosi anak akan sangat memengaruhi perkembangan anak di masa depan, termasuk juga dalam perkembangan moral dan sosial. Kondisi keluarga yang melaksanakan fungsinya dengan baik dalam hal kesehatan dan kesejahteraan berpengaruh pada perilaku remaja (Williams \& Anthony, 2015). Gottfredson dan Hirschi (1990) menyatakan bahwa kelekatan yang kuat diantara orang tua dan anak akan menuntun pada monitoring yang efektif dan perilaku disiplin selama dekade pertama kehidupan anak, yang menghasilkan kemampuan menolak hal-hal yang negatif. Ditemukan bahwa ikatan hubungan yang hangat, mendalam dan berkualitas antara orang tua dan anak serta remaja mampu membantu anak praremaja dalam mengatasi perubahanperubahan yang terjadi di dalam dirinya (Ainsworth, 1979). Kelekatan orang tua dengan anak berhubungan signifikan dengan berbagai tipe dari perilaku kenakalan remaja (Hoeve et al., 2009 ), salah satunya adalah perilaku pornografi. Kenakalan remaja dan tingginya perilaku berisiko negatif telah dihubungkan dengan kekacauan pada kelekatan orang tua dan kelekatan teman (Wampler \& Downs, 2010). Hubungan keluarga yang positif mengurangi kemungkinan untuk terlibat dalam perilaku bermasalah yang dilakukan secara online (Noll et al., 2013).

Kelekatan terdiri dari tiga dimensi yaitu kepercayaan (trust), komunikasi (communication) dan keterasingan (alienation) (Armsden \& Greenberg, 1987). Menurut Pierrehumbert et al. (2009), terdapat perbedaan antara kelekatan yang terbentuk pada anak laki-laki dan anak perempuan. Kelekatan anak dengan ibu yang lebih tinggi dibanding kelekatan ayah dikarenakan sejak kecil anak lebih banyak berinteraksi dengan ibu. Rasa percaya (trust) merupakan modal dasar bagi anak untuk membentuk kelekatan aman dengan ibunya. Anak yang rendah rasa empatinya dan penghargaan pada orang lain, 
serta melakukan tindakan asosial (kriminal), berhubungan dengan rendahnya rasa kepercayaan pada orang tua atau pengasuh utamanya di waktu kecil (Ainsworth, 1979). Kualitas komunikasi yang baik antara ibu dan anak juga sangat memengaruhi terbentuknya kelekatan ibu.

Tingginya nilai keterasingan bukan sesuatu yang baik dalam hubungan kelekatan ibu dengan anak. Nilai keterasingan yang relatif tinggi pada kelekatan ibu kemungkinan disebabkan oleh tingkat kesibukan ibu, baik aktivitas tambahan di luar (misalnya aktif berorganisasi) sehingga waktu yang disediakan untuk anak menjadi berkurang. Hal ini juga dapat dikarenakan kesibukan ibu di rumah dalam mengurus keluarga, mengingat lebih dari 50,0 persen contoh berasal dari keluarga sedang (5-7 orang). Sebanyak 40,4 persen contoh adalah anak pertama, yang berarti masih memiliki adik sekitar 2-4 orang dan kemungkinan ada yang berusia balita. Usia anak paling banyak berkisar 12-13 tahun. Pada tahap usia ini, rasa ingin tahu anak sangatlah besar (Santrock, 2011). Usia remaja awal ini menurut Erick Erikson adalah masa pencarian identitas versus kekacauan identitas (Santrock, 2011). Lingkungan anak juga semakin luas tidak terbatas di keluarga saja. Menurut Gault-sherman (2012) bahwa menurunnya keterlibatan ibu akan menyebabkan kelekatan anak dengan ibu akan menurun. Tingginya nilai keterasingan (alienation) anak dengan orang tua, akan memprediksi perilaku menyimpang dan perilaku agresif (Butler et al., 2007).

Peran ayah pada masa remaja awal ini sangatlah penting (Santrock, 2011). Ayah bertindak tidak hanya sebagai model bagi anak untuk pembentukan identitas dirinya, tapi juga sebagai manajer dan monitoring bagi anak. Kelekatan anak dengan ayah pada usia remaja awal merupakan pengalaman yang tidak bisa diabaikan. Lemahnya kelekatan ayah dengan anak laki-laki berhubungan negatif signifikan dengan kenakalan pada anak laki-laki (Hoeve et al., 2012). Penelitian yang dilakukan oleh Shahidul dan Karim (2015) mengobservasi bahwa anak yang memiliki kelekatan yang baik dengan orang tua, menunjukkan adanya pengaruh positif pada level aspirasi $(\beta 0=0,760$, $\mathrm{p}<0,01)$. Hasil ini mengindikasikan bahwa jika kelekatan orang tua dengan anak lebih besar, maka level aspirasi pelajar juga bertambah tinggi (Shahidul \& Karim, 2015). Penelitian ini dapat diinterpretasikan untuk kondisi sebaliknya pada perilaku yang negatif, dalam hal ini pornografi. Kelekatan orang tua yang tinggi akan menurunkan perilaku pornografi pada anak

Hasil penelitian ini juga menunjukkan bahwa nilai rata-rata perilaku pornografi pada anak laki-laki lebih tinggi daripada anak perempuan. Secara statistik, perbedaan perilaku pornografi pada anak laki-laki dan perempuan ini adalah signifikan. Hal ini sejalan dengan penelitian Weber et al. (2012), bahwa ada perbedaan yang signifikan dalam hal perilaku pornografi berdasarkan jenis kelamin anak. Dibandingkan remaja perempuan, remaja laki-laki mengatakan bahwa mereka lebih menyukai melihat pornografi dan hal itu adalah sesuatu yang dianggap menarik (Romito \& Beltramini, 2015). Menurut teori nature dalam gender, perbedaan laki-laki dan perempuan adalah kodrat, sehingga harus diterima, tidak dapat berubah dan bersifat universal (Feder et al., 1966). Dalam hal ini organ biologis laki-laki dan perempuan khususnya pada bagian alatalat reproduksi memang berbeda (Santrock, 2011). Perbedaan biologis ini dapat menyebabkan ketertarikan terhadap suatu hal pada laki-laki dan perempuan bisa berbeda. Penelitian Romito dan Beltramini (2015) membuktikan bahwa pornografi yang dilakukan anak laki-laki lebih sering daripada anak perempuan.

Hasil analisis regresi linier berganda menunjukkan bahwa variabel yang memiliki pengaruh signifikan terhadap perilaku pornografi adalah pendapatan keluarga, kelekatan remaja-ibu, dan kelekatan remajaayah. Kelekatan anak yang kuat dengan ibu dan ayah akan menurunkan risiko perbuatan bunuh diri pada anak (Heydari et al., 2015) atau perilaku negatif lainnya. Moss et al. (2006) menemukan bahwa pada kondisi kelekatan anak dengan orang tua yang tidak aman, permasalahan perilaku anak akan lebih tinggi.

Hasil penelitian menunjukkan bahwa peningkatan pendapatan keluarga akan meningkatkan perilaku pornografi. Kondisi sosial ekonomi keluarga akan berpengaruh terhadap perkembangan perilaku anak. Pendapatan keluarga yang tinggi dapat berhubungan dengan tingginya kesibukan ayah dan ibu. Ayah yang sibuk di luar rumah mencari nafkah, dapat menyebabkan waktu bertemu dengan anak juga semakin jarang. Pendapatan keluarga yang tinggi juga bisa menyebabkan ketersediaan kemampuan ekonomi untuk mendukung ibu beraktivitas di luar rumah. Penelitian yang dilakukan oleh Zhang (2012) membuktikan bahwa kondisi 
status sosial ekonomi keluarga seorang anak akan memiliki konsekuensi pada hubungan anak dengan orang tua. Kemungkinan karena pada penelitian ini alokasi penggunaan sumberdaya ekonomi yang dimiliki orang tua banyak digunakan untuk menyenangkan hati dan memberikan fasilitas fisik pada anak (misalnya, fasilitas telepon genggam, internet, dan sebagainya). Sebagian besar contoh penelitian memiliki fasilitas peralatan elektronik minimal satu unit dan jenis yang terbanyak adalah telepon genggam. Banyaknya kemudahan fasilitas yang diterima anak-anak dari orang tua menyebabkan peningkatan perilaku pornografi (Weber et al., 2012). Sikap orang tua yang memberikan otonomi atau kebebasan pada anak secara berlebih juga akan sangat berpengaruh pada anak. Orang tua yang sibuk akan cenderung memberikan banyak kebebasan pada anak, baik secara waktu maupun penggunaan fasilitas di rumah, misalnya fasilitas internet. Pada remaja yang diberikan otonomi, sebanyak 61,0 persen perempuan dan 93,0 persen laki-laki mengungkapkan pernah melihat video klip porno atau film porno (Weber et al., 2012).

Pada penelitian ini, sebanyak 59,7 persen anak laki-laki dan 76,5 persen anak perempuan diketahui dapat mengakses internet dari rumah. Fenomena perilaku pornografi merupakan akibat dari perkembangan teknologi yang begitu pesat seperti internet (Seto, 2010). Berbagai kemudahan yang diterima anak-anak, kebanyakan berasal dari orang tua mereka sendiri (Weber et al., 2012). Menurut penelitian D'Orlando (2011), motivasi psikologi yang signifikan dapat memengaruhi kebutuhan akan pornografi, keinginan tersebut bisa dibentuk oleh pendekatan adaptasi gaya hidup hedonik. Kemudahan untuk mengakses (Romito \& Beltramini, 2015) konten-konten porno di media sosial via gadget (telepon genggam, video, internet) yang diperoleh pada usia terlalu dini tanpa dibekali aturan yang tepat dalam penggunaannya, dapat menjadi salah satu sebab perilaku pornografi. Pada keluarga yang memiliki hubungan yang erat dengan anak dan melaksanakan fungsi monitoring anak dengan baik, maka akan menurunkan perilaku kenakalan pada anak (Hennerberger et al. 2013). Menurut penelitian Jonsson et al. (2015), lifestyle merupakan salah satu faktor yang berpengaruh pada perilaku pornografi. Luder et al. (2011) menyatakan bahwa parameter menggunakan internet juga signifikan berhubungan dengan pornografi. Semakin banyak anak terpapar dengan tontonan yang mengandung pornografi, akan meningkatkan kemungkinan anak melakukan perilaku pornografi. Namun hal ini tidak sejalan dengan penelitian yang dilakukan oleh Martin et al. (2010) bahwa latar belakang sosial ekonomi orang tua, kondisi stres di keluarga, dan kondisi emosi orang tua akan menimbulkan problem perilaku pada anak. Penelitian Kumari et al. (2014) juga menemukan adanya perbedaan signifikan tingkat agresivitas dan perilaku negatif pada anak yang berasal dari keluarga sosial ekonomi dan strata rendah di India.

Penelitian ini menemukan bahwa kelekatan ibu termasuk tinggi, dan kelekatan ayah termasuk sedang. Perilaku pornografi anak termasuk rendah. Hasil penelitian menunjukkan bahwa kelekatan anak dengan ibu dan ayah menunjukkan hubungan negatif signifikan dengan perilaku pornografi anak, artinya semakin tinggi kelekatan ibu dan ayah, maka perilaku pornografi cenderung akan menurun. Hal ini sejalan dengan penelitian Rivera et al. (2016) bahwa model hubungan yang positif dalam keluarga, dihubungkan dengan penurunan konsumsi pornografi online maupun offline. Kelekatan orang tua yang tinggi akan menurunkan perilaku pornografi pada anak. Hal ini sejalan juga dengan attachment theory (Ainsworth, 1979) bahwa anak yang memiliki kelekatan yang baik dengan orang tua, akan memiliki kemampuan menahan diri dari perilaku yang negatif. Hal ini tidak sejalan dengan penelitian Situmorang et al. (2016) bahwa tidak ada pengaruh yang signifikan antara kelekatan remaja dan orang tua terhadap seluruh dimensi karakter remaja perdesaan di Bogor, namun kelekatan berpengaruh signifikan terhadap karakter anak usia prasekolah di kota yang sama (Dewanggi et al., 2015). Anak perempuan yang memiliki kelekatan yang aman dengan ibunya dan menerima dukungan sosial dari ibunya dilaporkan memiliki banyak pengalaman yang positif dan hanya sedikit yang memiliki pengalaman perilaku negatif (Abraham \& Kerns, 2013). Corwin (2012) juga menyatakan bahwa kelekatan yang aman merupakan dasar yang terbaik untuk menjadi pembelajar yang andal. Orang tua dan teman memainkan peran yang penting dan unik pada perilaku antisosial pada remaja (Mobarake et al., 2014). Sejalan dengan penelitian ini, van Eijck (2012) dalam studi longitudinal menemukan bahwa sikap penerimaan orang tua pada remaja dan kualitas hubungan kelekatan antara orang tua dengan anaknya, memberikan pengaruh yang signifikan negatif terhadap gejala generalized anxiety disorder (GAD) pada remaja, dan anak laki-laki lebih banyak yang mengalaminya. 


\section{SIMPULAN DAN SARAN}

Kelekatan ibu nilainya lebih tinggi daripada kelekatan ayah. Dimensi kepercayaan pada kelekatan ibu lebih tinggi daripada kelekatan ayah. Hal ini dapat dipahami karena sejak kecil anak telah dekat dengan ibu sehingga jalinan kepercayaan sudah terbentuk sejak lama. Meskipun demikian, ayah juga harus berusaha agar anak dapat lebih mempercayainya. Nilai kelekatan ayah pada dimensi komunikasi lebih tinggi daripada kelekatan ibu. Hal ini dapat diartikan bahwa anak mengharapkan perhatian segera dari ibu bila ada masalah. Anak juga berharap ibu segera bertanya, dan mau membahas masalahnya bersama. Nilai kelekatan ibu pada dimensi keterasingan lebih tinggi dibanding kelekatan ayah. Ibu sebaiknya dapat mengatur waktunya sebaik mungkin agar anak tetap merasa diperhatikan oleh ibu dan tidak merasa diacuhkan. Ayah juga perlu selalu menjaga kedekatan dengan anak. Memanfaatkan waktu pertemuan dengan anak secara efektif dan efisien akan sangat berarti bagi kelekatan anak dengan ayah.

Kelekatan ini menjadi modal bagi anak untuk dapat menolak perilaku negatif seperti pornografi. Orang tua sudah semestinya menjaga kelekatan yang baik dengan anak. Orang tua juga wajib mengalokasikan waktu khusus untuk melakukan kegiatan yang menarik bersama anak. Pada saat orang tua melihat anak merasa sedih atau marah, segeralah tanyakan pada anak, tunjukkan rasa empati, dan bantulah anak untuk memecahkan masalahnya.Orang tua perlu menunjukkan perhatian dan penghargaan pada anak, misalnya dengan cara mendengarkan dengan seksama saat anak menceritakan masalahnya. Berilah kepercayaan pada anak dengan tetap melakukan monitoring yang tepat.

Hasil penelitian memperlihatkan bahwa nilai rata-rata anak laki-laki dalam hal perilaku pornografi lebih tinggi daipada anak perempuan. Perhatian pada anak laki-laki terhadap kemungkinan terpapar pornografi harus lebih ditingkatkan untuk mencegah agar anak tidak terjerumus. Pemberian fasilitas pada anak harus dipertimbangkan sebaik mungkin. Pemberian fasilitas tanpa monitoring yang kuat dari orang tua, justru dapat mendorong anak pada perilaku pornografi.

\section{DAFTAR PUSTAKA}

Ainsworth, M. D. S. (1979). The Development of infant-mother attachment. Cadwell and H. Ricciuti (Eds) Review of Child
Development Research (Vol.3.pp1-94). Chicago, US: University of Chicago Press.

Al-Fadhli, S. M., Abbas, H. A., Dashti, A. A., Hamdi, H. (2014). The ethical attitudes toward internet pornography in islamic societies: Kuwait as a case study. Journal of Information Ethics, 23(2), 6070. doi:10.3172/JIE.23.2.60.

Armsden, G. C., \& Greenberg, M. T. (1987). The inventory of parent and peer attachment: Individual differences and their relationship to psychological wellbeing in adolescence. Journal of Youth and Adolescence, 16, 427-454.

[APJII] Assosiasi Pengguna Jaringan Internet Indonesia. (2014). Data pengakses internet di Indonesia. Diambil dari https://www.apiii.or.id/. [Diunduh pada: 20 September 2016].

Abraham, M. M., \& Kerns, K. A. (2013). Positive and negative emotions and coping as mediators of mother-child attachment and peer relationships. Merrill-Palmer Quarterly, 59(4), 399-425.

Butler, S., Fearon, P., Atkinson, L., \& Parker, K. (2007). Testing an interactive model of symptom severity in conduct disordered youth: family relationships, antisocial cognitions, and socialcontextual risk. Criminal Justice and Behaviour, 34, 721- 738.

Corwin, H. L. (2012). A secure attachment base is ideal to be a great learner. Journal of Prenatal \& Perinatal Psychology \& Health, 27(1), 38-46.

[Disnakertrans] DinasTenaga Kerja dan Transmigrasi. (2014). Upah minimum regional. Diambil dari http :// disnakertrans. Diambil dari bantenprov. go.id/.[Diunduh 4 Januari 2017].

D'orlando, F. (2011). The demand for pornography. Journal of Happiness Studies, 12(1), 51-7. doi:http:// dx.doi .org/ 10.1007/ s10902-009-91750.

Dewanggi, M., Hastuti, D., \& Herawati, T. (2015). The influence of attachment and quality of parenting and parenting environment on children's character in rural and urban areas of Bogor. Jurnal IImu Keluarga dan Konsumen, 8(1), 2027.

Feder, H. H., Phoenix, C.H., \& Young, W.C. (1966). Suppressuion of feminine behavior by administration of 
testosterone propionate to neonatal rats. Journal of Endocrinology, 34(1), 131-132

Gottfredson, M. R., \& Hirschi, T. (1990). A general theory of crime. Standford, US: Standford University Press.

Gault-sherman, M. (2012). It's a two-way street: The bidirectional relationship between parenting and delinquency. Journal of Youth and Adolescence, 41(2), 121-45. doi:http:// dx.doi.org/10.1007/s10964-011-9656-4.

Heydari, A., Teymoori, A., \& Nasiri, H. (2015). The effect of parent and peer attachment on suicidality: The mediation effect of self-control and anomie. Community Mental Health Journal, 51(3), 359-364. doi:http://dx.doi.org/10.1007/s10597014-9809-5.

Henneberger, A. K., Durkee, M. I., Truong, N., Atkins, A., \& Tolan, P. H. (2013). The longitudinal relationship between peer violence and popularity and delinquency in adolescent boys: Examining effects by family functioning. Journal of Youth and Adolescence, 42(11), 1651-60. doi:http://dx.doi.org/10.1007/s10964012-9859-3

Hoeve, M., Dubas, J. S., Eichelsheim, V. I., van der Laan, P. H., Smeenk, W., \& Gerris, J. R. M. (2009). The Relationship Between Parenting and Delinquency: A Meta-analysis. Journal of Abnormal Child Psychology, 37(6), 749-775. doi:http://doi.org/10.1007/s10802-0099310-8

Hoeve, M., Stams, G. J. J. M., van der Put, C. E., Dubas, J. S., van der Laan, P. H., \& Gerris, J. R. M. (2012). A Meta-analysis of Attachment to Parents and Delinquency. Journal of Abnormal Child Psychology, 40(5), 771-785. doi:http://doi.org/10.1007/s10802-0119608-1

Jonsson, L. S., Bladh, M., Priebe, G., \& Svedin, C. G. (2015). Online sexual behaviours among swedish youth: Associations to background factors, behaviours and abuse. European Child and Adolescent Psychiatry, 24(10), 1245-1260.

doi:http://dx.doi.org/10.1007/s00787015-0673-9

[KNPA] Komisi Nasional Perlindungan Anak. (2011). Data perilaku remaja. Diambil dari komnasanak.com. [diunduh pada 20 Juni 2016].
[Kemenag] Kementrian Agama RI. (2008). Undang-undang pornografi. Diambil dari http://www.kemenag.go.id/. [diunduh pada 4 januari 2017].

Kumari, V., Kang, T. K., \& Princy. (2014). Aggression among adolescents across different socio-economic developmental strata: A comparative study. Indian Journal of Health and Wellbeing, 5(10), 1194-1197.

Kraus, S., \& Rosenberg, H. (2014). The pornography craving questionnaire: Psychometric properties. Archives of Sexual Behavior, 43(3), 451-62. doi:http://dx.doi.org/10.1007/s10508013-0229-3.

Luder, M., Pittet, I., Berchtold, A., Akré, C., Michaud, P., \& Surís, J. (2011). Assocoations between online pornography and sexual behavior adolescents: myth or reality? Archieves of Sexual Behavior, 40(5), 1027-1035.doi:http://dx.doi.org/10.1007/s 10508-010-9714-0

Mariani A, \& Bachtiar I. (2010). Keterpaparan materi pornografi dan perilaku seksual siswa sekolah menengah pertama negeri. Jurnal Makara, Sosial Humaniora, 14(2), 83-90.

Martin, M. J., Conger, R. D., Schofield, T. J., Dogan, S. J., Widaman, K. F., Donnellan, M. B., \& Neppl, T. K. (2010). Evaluation of the interactionist model of socioeconomic status and problem behavior: A developmental cascade across generations. Development and Psychopathology, 22(3), 695-713. doi:http://dx.doi.org/10.1017/S09545794 10000374

Mobarake, R. K., Juhari, R., Yaacob, S. N., \& Esmaeili, N. S. (2014). The moderating role of self-control in the relationship between peer affiliation and adolescents antisocial behavior in tehran, iran. Asian Social Science, 10(9), 71-81. doi:http://dx.doi.org/10.5539/ass.v10n9p 71.

Moss, E., Smolla, N. C. Y. R. C., DuboisComtois, Karin, E., Mazzarello, T., \& Berthiaume, C. (2006). Attachment and behavior problems in middle childhood as reported by adult and child informants. Development and Psychopathology, 18, 425-444.

Noll, J. G., Shenk, C. E., Barnes, J. E., \& Haralson, K. J. (2013). Association of maltreatment with high-risk internet 
behaviors and offline encounters. Pediatrics, 131(2), e510e517.

Pierrehumbert, B., Santelices, M. P., Alberdi M. I. M., Ongari, B., Stievenart, I. R.M., Spences, R., Rodriguez, A. F. \& Borghini, A., (2009). Gender and attachment representations in the preschool years. comparisons between five countries. Journal of Cross-Cultural Psychology, 40(4), 543-566.

Romito, P., \& Beltramini, L. (2015). Factors associated with exposure to violent or degrading pornography among high school students. The Journal of School Nursing, 31(4), 280-290. doi:http://dx.doi. org/ 10.1177/1059840514563313.

Rivera, R., Santos, D., Cabrera, V., \& Docal, M. (2016). Online and offline pornography consumption in colombian adolescents. Comunicar, 24(46), 37-45. doi:http://dx.doi.org/10.3916/C46-201604.

Sabina, C., Wolak, J., \& Finkelhor, D. (2008). The nature and dynamics of Internet pornography exposure for youth. CyberPsychology \& Behavior, 11(6), 691-693.

Santrock, J. W. (2011). Life-span development: thirteenth edition. New York, US: McGraw-Hill.

Seto, M. C. (2010). Child pornography use and internet solicitation in the diagnosis of pedophilia. Archives of sexual behavior, 39(3), 591-593. doi:http://dx.doi.org/10.1007/s10508010-9603-6

Seto, M. C., Hermann, C. A., Kjellgren, C., Priebe, G., Svedin, C.G., \& Långström, N. (2015). Viewing child pornography: prevalence and correlates in a representative community sample of young swedish men. Archives of Sexual Behavior, 44(1), 67-79. doi:http://dx.doi.org/10.1007/s10508013-0244-4.

Shahidul, S. M., \& Karim, A. H. (2015). Intergenerational bonding in family and school contexts: which does impact more on degree aspiration of students?. Asian Social Science, 11(27), 63-70. doi:10.5539/ass.v11n27p63.

Situmorang, Z. R., Hastuti, D., \& Herawati, T. (2016). Pengaruh kelekatan dan komunikasi dengan orang tua terhadap karakter remaja perdesaan. Jurnal IImu Keluarga dan Konsumen, 9(2), 113-123. doi:

http://dx.doi.org/10.24156/jikk.2016.9.2.1 13.

Smallbone, S. W., \& Dadds, M. R. (2000). Attachment and coercive sexual behavior. Sexual Abuse: A Journal of Research and Treatment, 12(1), 3-15.

van Eijck, F. E., A, , M., Branje, S. J., T., \& Hale, W. W. (2012). Longitudinal associations between perceived parentadolescent attachment relationship quality and generalized anxiety disorder symptoms in adolescence. Journal of Abnormal Child Psychology, 40(6), 87183. doi:http://dx.doi.org/10.1007/s10802012-9613-z.

Wampler, R. S., \& Downs, A. B. (2010). Parent and peer attachment in minority males at high risk for delinquency. Clinical Social Work Journal, 38(1), 107-119. dx.doi.org/10. 1007/ s 10615-009 -02398.

Weber, M., Quiring, O., \& Daschmann, G. (2012). Peers, parents and pornography: exploring adolescents' exposure to sexually explicit material and its developmental correlates. Sexuality \& Culture, 16(4), 408-427. doi:http://dx.doi.org/10.1007/s12119012-9132-7.

Williams, L. R., \& Anthony, E. K. (2015). A model of positive family and peer relationships on adolescent functioning. Journal of Child and Family Studies, 24(3), 658-667. doi:http:// dx.doi. org/ 10.1007/ s10826-013-9876-1.

Zhang, X. (2012). The effects of parental education and family income on motherchild relationships, father-child relationships, and family environments in the people'srepublic of china. Family Process, 51(4), 483-97. 